\title{
EMPLOYER SANCTIONS FOR VIOLATION OF NO-STRIKE CLAUSE: UNION BUSTING THROUGH MASS DISCHARGE AND RESCISSION*
}

EMPLOYERS often secure no-strike clauses ${ }^{1}$ in collective bargaining contracts ${ }^{2}$ with their employees' unions, ${ }^{3}$ in order to ensure greater union responsibility for the maintenance of stable production schedules. 4 Under such clauses, the union promises not to authorize or sanction any strike during the term of its contract. ${ }^{5}$ The employer is usually given power to discipline or discharge all the individual union members who strike in violation of the no-strike clatuse. ${ }^{0}$

\footnotetext{
*Marathon Electric Mfg. Corp., 106 N.L.R.B. No. 199, 32 LaB. Ret. REF. MaN. 1645 (1953).

1. Approximately 89 percent of all collective bargaining contracts in the United States contain some form of no-strike clause. Approximately nine out of ten of those contracts without specific no-strike clauses provide for arbitration or grievance procedure in disputes. BNA, Collective Bargaining Negotintions and Contracts $15: 325$ (1954) (hereinafter cited as CBNC). Failure to employ arbitration or gricvance procedures before striking has been treated as if it were a no-strike violation. See NLRB v. Darsey Trailers, Inc., 179 F.2d 589 (5th Cir. 1950). A recent decision indicates that a no-strike clause may have been written into every collective bargaining agreement by operation of the Labor Management Relations Act of 1947 (hereinafter cited at LRMA), 61 STAT, 136 (1947), 29 U.S.C. $\S \S 151$ et seq. (Supp. 1952). See Local No. 3, United Packinghouse Workers of America, CIO v. NLRB, 210 F.2d 325, 332-3 (8th Cir. 1954).

Provisions against employer lockouts are included in approximately 74 percent of all contracts. CBNC, supra at $15: 325$. Under many agreements, the prohibition against lockouts is not applicable when the union has violated the no-strike clause; the employer may shut down pending assurances of no future violations. P-H LAB. AR8. SERv. If 65,371.

2. In order to be binding upon a union, the no-strike clause must be incorporated in the contract. A mere union pledge not to strike is not enforceable against a union. Consolidated Frame Co., 91 N.L.R.B. 1295 (1950). See also 14 NLRB Ann. Rer. 65 (1949).
}

3. A no-strike clause in an individual employment contract is illegal on the theory that such a clause deprives a worker of his statutory right to strike. Cf. Berkshire Knitting Mills, 46 N.L.R.B. 955, 1006 (1943). See also cases cited P-H La1. REt. SEnv. đf 20,791.1(5) (1954). However, this theory has not been maintained in collective contratcts; an employer is allowed to insist upon a no-strike clause. See N.L.R.B. v. Norfolk Shipbuilding and Drydock Co., 195 F.2d 632 (4th Cir. 1952). But cf. N.L.R.B. v. Tower Hosiery Mills, Inc., 180 F.2d 701 (4th Cir. 1950) (insistence upon overly stringent no-strike clause used as evidence of intent to refuse to bargain).

4. For discussion of the purpose of no-strike clauses, see, generally, SMrTH, LAnow Laws, Cases and Materials 770 (2d ed. 1953) ; 1952 Report of the Committce on Improvement of Administration of Union-Employer Contracts, Section of Labor Relations Law, American Bar Association, The No-Strike Clause (hercinafter cited as ABA Report), 21 Geo. Wash. L. Rev. 127, 128 (1952); Daykin, The Na-Strike Clatse, 11 U. of Pitr. L. Rev. 13, 13-14 (1949).

5. The extent to which the no-strike clause is applicable varies in different contracts. These may be divided generally into two categories: unconditional and conditional. Unconditional clauses are unequivocal abridgements of the right to strike. Forty percent 
When confronted with a union-sponsored strike in violation of a no-strike clause, the employer may be forced to accede to the union's demands because of production requirements or the scarcity of replacement workers. ${ }^{7}$ Alternatively, he may shut down his plant and wait out the strike, disciplining the strikers when they return to work, subject to an arbitrator's review. ${ }^{3}$ However, if he believes his bargaining position to be strong, he may discharge all the strikers, rescind the contract, and refuse thereafter to deal with the union. ${ }^{9}$ The National Labor Relations Board has upheld such employer actions on the grounds that they are justified by the union's prior material breach of the contract, ${ }^{10}$ and that strikers in violation of contract are not protected by the National Labor Relations Act.11

of contracts contain such clauses. CBNC, supra note 1, at 15:326. Conditional clauces abridge the general right to strike but retain it in certain circumstancss (c.g., upon eshaustion of the grievance procedure, or upon a majority vote of the union membsrship), or upon certain issues (c.g., wage reopener disputes, or worls load changes). For examnles of different types of no-strike clauses, see CBNC, supra note 1, at 77:1-904.

6. The penalty provisions of many no-strike clauses duclare that violators are suljicet to discipline or discharge CBNC, surra note 1 , at 15:32 Sone provile for spreifis penalties of a lesser-than-discharge nature. Ibid. For general discussion see P-H L'II: Contr. SeRv. III 53,402-3 (1954). For specific types of lesser-than-discharge panalties, see note 72 infra.

The union normally exempts itself by contract from liability arising from unauthorized strikes. ABA Report, 21 Gro. Wast. L. REv. 127, 146-151 (1952). Howtver, some cuntracts call for sanctions against the union for unauthorized ny-strike violations, if the union fails to take specific steps to end the strike. CBNC, supra nute 1, at $77: 275$ of sco. Cf. United Elastic Corp., 44 N.L.R.B. 768 (1949) (union made respunsible by Board for failure to disavow wildcat walkout).

7. An employer who agrees unconditionally to reinstate no-strike violators is bound to this decision on the theory that he has waived his right to enfurce puraitics. Alabama ILarble Co., \&3 N.L.R.B. 1047 (1949), cnforced, 185 F.2d 1022 (5th Cir. 1951); Carcy Salt Co., 70 N.L.R.B. 1099 (1946); Columbia Pictures Corp., S2 N.L.R.B. 568 (1949). But cf. Fafnir Bearing Co., 73 N.L.R.B. 1008 (1947) (employer could refuse to reemrloy union leaders after offer of reinstatement). However, a conditional offer of rcinstatement does not constitute a waiver unless the striking employees fulfill the specified conditions. United Elastic Corp., S4 N.L.R.B. 768 (1949) (time limitation placed upen reinstatement offer). The conditions may not be discriminatory. Eagle-Picher Mining \& Smelting Co., 119 F.2d 903 (Sth Cir. 1941).

8. See text at notes $41-2$ infra.

9. See, e.g., Boeing Airplane Co. v. NLRB, 174 F.2d 988 (D.C. Cir. 1949) (rescission and mass discharge) ; Marathon Electric MIfg. Co., 106 N.L.R.B. No. 199, 32 LAB. KEI. REF. Mar. 1645 (1953) (mass discharge, rescission, refusal to bargain); United Elastic Corp., S4 N.L.R.B. 768 (1949) (rescission, refusal to bargain, mass discharge).

10. See Boaing Airplane Co. v. NLRB, 174 F.2d $98 S$ (D.C. Cir. 1949) (rescission permitted without discussion); Marathon Electric MIfg. Corp., 105 N.L.R.B. No. 199, 32 Lab. ReI. ReF. Jlaiv. 1645 (1953) (same). But of. Unitcd Elastic Corp., \& N.L.R.B. 768 (1949) (rescission termed irrelevant).

11. 49 Stat. 452 (1935) as amended, 61 Srat. 136 (1947), 29 U.S.C. $\$ \$ 151$ et sol. (Supp. 1952) (hereinafter cited as NLRA or Act). The doctrine that contract violators are not protected by the Act was first handed down in NLRB v. Sands Mifg. Co., 305 U.S. 332 (1939), and has been followed consistently by the Eoard. See, c.y., Scullin Stud 
$\bullet$

The recent case of Marathon Electric Manufacturing Corp. ${ }^{12}$ involved the latter type of employer sanctions. A dispute arose concerning interpretation of the collective bargaining agreement. ${ }^{13}$ Upon the breakdown of negotiations, the leadership of the United Electrical Workers local violated the no-strike clause by calling the entire first shift out of the plant to attend a union meeting. ${ }^{14}$ Marathon immediately locked the gates, thereby denying admittance to second and third shift workers. ${ }^{15}$ The next day it sent a letter purporting to discharge, under the no-strike clause, all "participants" in the strike, ${ }^{10}$ and a week later it rescinded the contract with UE.17 Three weeks after the start of the strike, the company reopened the plant, ${ }^{18}$ and began to hire a substantially new working force. ${ }^{19}$ A different union, assisted by the management in organizing the newly hired employees, was then granted recognition. ${ }^{20}$

UE appealed to the NLRB,21 alleging that Marathan had discriminated against the union by its mass discharge and rescission, violating Sections

Co., 65 N.L.R.B. 1294 (1946); Joseph Dyson \& Sons, Inc. 72 N.L.R.B. 445 (1947); National Electric Products Corp., 80 N.L.R.B. 995 (1948). Exceptions to the general rule are the cases where the employer has waived the right to penalize, see note 7 supra, and where the strike has been precipitated by the employer's unfair labor practice, sce note 67 infra.

12. 106 N.L.R.B. No. 199, 32 LAR. Rex. Ref. MaN. 1645 (1953).

13. The disputed issue was a wage increase which had been rejected by the Wagc Stabilization Board. UE demanded the increase in fringe benefits, and Marathon refuscd. Communication to the YaIE LAw Journal from Calvin O. Crocker, Labor Relations Director, Marathon Electric Mfg. Corp., dated May 17, 1954, in Yale Law Library.

14. The walkout occurred at 2:00 P.M. on February 28, 1952. Marathon Electric Mfg. Corp., 106 N.L.R.B. No. 199, p. 3, 32 Lab. Rez. Ref. MAN. 1645, 1646 (1953). The no-strike clause provided, in part: ". . . the union will not authorize or sanction any strike ... and the Company will not lock out the employees. ... In case any such action ... shall occur ... any or all of the employees taking part will be subject to discipline or discharge." Id. at 2, 32 LAB. REL. REF. MAN. at 1646.

15. The plant was completely shut down by 2:40 P.M. the same day. Id. at 3, 32 Lab. ReL. Ref. MAN. at 1646.

16. Id. at 4, 32 LAB. REI. ReF. MAN. at 1646.

17. The rescission was announced by letter to all employees on March 5, 1952. Ibid. In addition, Marathon discharged four UE members who had remained on the job as watchmen after the walkout and two non-union office workers whose husbands were members of UE. Id. at 4-5, 32 LAB. Ret. REF. MAN. at 1648, 1650.

18. Id. at 5, 32 LAB. Red. ReF. MAN. at 1650.

19. Only 49 UE members were rehired by Marathon out of a normal working force of 450-550. Communcation to the YaLe LAw Jouras from Calvin O. Crocker, Labor Relations Director, Marathon Electric Mfg. Corp., dated May 17, 1954, in Yale Law Library. It took a substantial period of time for Marathon to hire its new working force: two weeks after it reopened the plant, it was operating with only 39 workers; and twelve weeks after reopening it was employing only 115 workers. Marathon Electric Mfg. Co., 106 N.L.R.B. No. 199, pp. 5, 6, 32 LAB. Rel. Ref. MaN. 1645, 1650, 1651 (1953).

20. A local of the International Brotherhood of Electrical Workers, AFL, (IBEW) was recognized by the employer as the employees' bargaining agent on June 9, 1952. Ibid.

21. The General Counsel of the NLRB assumed the burden of UE's case under NLRB procedure. See 29 Code FED. REGS. $\S \S 101.8,101.10,101.11$ (b) (1949). 
$8(a)$ (1) and $8(a)$ (3) of the Act.22 Its theory was that the strike had ended on the day of the walkout when the union leaders ordered the men back to work, so that Marathon's refusal to admit the employees who subsequently appeared at the plant gates constituted a lockout. ${ }^{23}$ The union demanded reinstatement of the workers who had been denied admittance and of the laid-off workers who had been denied recall because of the rescission. ${ }^{24}$ It also asked for resumption of its bargaining rights. ${ }^{25}$

The Board, however, considering each employer action separately, ruled generally for Marathon. Since UE had never unequivocally informed Marathon that the walkout had ended, ${ }^{26}$ the Board held that the company could assume that it was continuing and therefore did not have to bargain with the union. ${ }^{27}$ The Board stated that the appearance of the workers at the plant gates on the day of the walkout was merely a "tactical maneuver." Mi Moreover, it found

22. Section $S(a)$ (1) provides: "It shall be an unfair labor practice for an employer to interfere with, restrain, or coerce employees in the exercise of the rights guarantecd in Section 7 of this title." (Section 7, 29 U.S.C. $\$ 157$ (1946), guarantees employees the right of self-organization).

Section 8(a) (3) provides: "It shall be an unfair labor practice for an employer by discrimination in regard to hire or tenure of employment or any term or condition of employment to encourage or discourage membership in a labor organization." 49 Srar. 452 (1935), as amended, 61 Star. 140 (1947), 29 U.S.C. $\$ 158$ (Supp. 1952).

For specific contentions of General Counsel, see Marathon Electric Míg. Corp. 105 N.L.R.B. No. 199, pp. S-14, 32 LAB. ReI. REF. MLA. 1645, 1647-9 (1953).

23. Id. at 13, 32 LAB. REL. REF. MIAN. at 1649. An employer who shuts down his operations or prevents his employees from working in order to affcet their choice of union or to avoid bargaining with a union is guilty of discrimination in violation of $\$ \$ \&(a)(1)$ and 8 (a) (3). See note 22 supra. NLRB v. Somerset Classics, Ine, 193 F.2d 613 (2d Cir.), cert. denicd sub nom. Modern Mffg. Co. v. NLRB, 344 U.S. S16 (1952) ; NLRB v. Stremsl, 141 F.2d 317 (10th Cir. 1944). See also cases cited in P-H L.ad. Rer. Serv. T 21,133 (1954). And see Comment, Legality of Employer's Use of Lockout, 51 Mícr. L. REv. 419 (1953). A shutdown in the face of a strike is not always discriminatory. Sce note $29 \mathrm{infro}$.

24. Marathon Electric Mfg. Corp., 106 N.L.R.B., No. 199, pp. 9, 11, 32 Lad. ReI. RaF. IIAN. 1645, 1647, 1645 (1953). The General Counsel conceded that the workers on the first shift who had walked out were not entitled to protection. Id. at p. 7, 32 L.ar. Rn. REF. MAN. at 1647.

25. Id. at 14, 32 LAB. REL. REF. MAN. at 1650. UE's theory was that if the 62 absentees and 105 laid-off employees were reinstated, Marathon would be required by law to bargain with UE.

26. The Board felt that UE had not stated that the strike was ended, but rather had stated its wish to negotiate concerning its end. Id. at 14, 32 L.AB. REI. REF. MLs:. at 1649.

27. Employers generally are under a duty to bargain with their employees" union during a strike See cases cited in P-H LAB. REz. SERv. If 21,972 (1954). However, if the strike is in violation of contract, there is no duty to bargain until the strilse is terminated. See, e.g., Higgins, Inc, 90 N.L.R.B. 184 (1950); United Elastic Corp., \&4 N.L.R.B. 769 (1949).

28. Marathon Electric Mfg. Corp., 106 N.L.R.B. No. 199, p. 10, 32 Lae. ReI. ReF. MIAN. 1645, 1648 (1953). The Board found this a "tactical maneuver" breause the UE leadership did not order the men back until after it learned that the gates were closed. It also referred to a similar instance in a previous UE strilke. UE had conductcd strilies at Marathon in 1941 and 1946. Communication to the YaLE LAW Joursal from Calvin 
economic justification for shutting down the plant during the strike. ${ }^{29}$ Because the union itself was responsible for the strike and because no workers "disassociated" themselves from the union's actions, the Board held that Marathon could discharge the entire union membership as strikers in violation of contract. ${ }^{30}$ Those who were validly discharged under this rationale included absentees and second and third shift workers who were "fortuitously" not present in the plant at the time of the walkout. ${ }^{31}$ The Board further held that UE's prior breach of the contract enabled Marathan to rescind it, ${ }^{32}$ thereby denying to the 105 previously laid-off workers whatever seniority rights and rehiring priorities they possessed. ${ }^{33}$

O. Crocker, Labor Relations Director, Marathon Electric Mfg. Corp., dated May 17, 1954 , in Yale Law Library.

29. Marathon Electric Mfg. Corp. 105 N.L.R.B. No. 199, p. 8, 32 LAw. Rel. Rer. MAN. 1645,1647 (1953). The shutdown was economically justified because the employer did not know how long the walkout would last; and the second and third shifts merely serviced and supplied parts to the first shift, making it economically wasteful to contintte production, without the first shiit. Id. at p. 8, 32 LAB. REt. REF. M $\Lambda$ N. at 1647. For other examples of economically justified shutdowns, see International Shoc Co., 93 N.L.R.B. 907 (1951) (shutdown of integrated plant justified when two departments struck); Duluth Bottling Association, 48 N.L.R.B. 1335 (1943) (shutdown justified becatse of anticipated spoilage). See also Comment, Legality of Employers' Usc of Lockout, 51 Mich. L. Rev. 419 (1953); 22 Geo. WAsh. L. Rev. 248 (1953). Some courts feel that a lockout is at legal device for use in any strike situation. See Morand Bros. Beverage Co. v. NLRB 204 F.2d 529, 534 (7th Cir. 1953).

30. The Board based its finding of no express disassociation on the fact that Marathon's "employees ... were members of a strong and militant local . . . under a [union shon] contract.... [T] in the plant at the time it took place. The record is silent as to any showing of dissent among these [non-present] employees. ..." Marathon Electric Mfg. Corp., 106 N.L.R.B. No. 199, p. 9, 32 LAB. REL. REF. MaN. 1645, 1647 (1953).

The Bureau of National Affairs stated that the Board found "constructive participation" by the non-present workers. 32 BNA, LAB. REL. ReF. MAN. ANal. 93 (1953). It further felt that the militancy, union shop, and "tactical maneuver" were limitations to the future application of Marathon. Ibid. See also 22 GEo. WASE. L. REv. 248 (1953) for criticism of this phase of the decision as placing excessive responsibility upon individuals for the union's acts.

31. There were 62 employees in this category, Marathon Electric Mfg. Corp, 100 N.L.R.B. No. 199, p. 9, 32 LAB. Rez. Ref. Man. 1645, 1647 (1953). They constituted approximately 12 percent of the work force. Id. at pp. 2, 9, 32 LAB. REt. REF. MAN، at $1646,1647$.

32. Id. at 11, 32 LAB. REL. REF. MAN. at 1650.

33. The rescinded contract granted to these employees first priority to fill any vacancies at Marathon. Marathon Electric Mfg. Corp. 106 N.L.R.B. No. 199, p. 4, 32 LAw. Rez. Ref. MAN. 1645, 1648 (1953).

The Board ruled against Marathon in these respects: it ordered reinstatement with back pay for four watchmen and two office employees who had been discriminaturily discharged because of their union membership. Id. at 7, 12,19,32 LAB. ReL. Rer. MAN. at 1648-9. It further revoked the recognition given IBEW, see note 20 supra, on the thcory that no substantial and representative working force existed at the time the union was recognized, $i d$. at p. 15, 32 LAB. REL. REF. MAN. at 1650, following the rule established in Coast Pacific Lumber Co., 78 N.L.R.B. 1245 (1948). However, IBEW was soon validly certified as bargaining agent for the employees. See note 38 infra. 
The NLRB has consistently denied the employer the right to affect, by employment or discharge, his employees' choice of union. ${ }^{34}$ Occasional discharge penalties for no-strike violations admittedly serve as deterrents to future strikes. ${ }^{35}$ Moreover, discharge is explicitly authorized by many contracts incorporating no-strike clauses and therefore is a justifiable disciplinary measure. $^{36}$ And Section S(d) of the NLRA may be construed to allow the employer to treat no-strike violators as having forfeited their rights as employees under the Act. ${ }^{37}$ But in Marathon, by permitting a mass discharge followed by contract rescission and refusal to bargain, the Board enabled the company permanently to oust the striking union as bargaining agent for its employees. ${ }^{38}$ Since Marathan followed its discharge notice with an offer to rehire the discharged workers, ${ }^{39}$ its aim in effecting the mass discharge was not primarily to discipline individual strikers but to oust the union. Its other actions, considered together, support this conclusion. ${ }^{10}$

34. Section 8 (a) (3) clearly states this policy. See note 22 stfra. The questions concerning application of $\$ \$(a)$ (3) have therefore dealt primarily with the proof of discrimination rather than the principle. See cases cited P-H LaB. Rer. SEnv. If 21,125, $21,134,21,135$ (1954).

35. See ABA Report, 21 GEo. WAsh. L. REr. 127, 172 (1952).

36. See note 6 supra.

37. Section \$(d), 61 Stat. 142, 143 (1947), 29 U.S.C. $\$ 15 \$$ (Supp. 1952), outlines the procedure under which a union may strike for termination or modification of a cullcative bargaining contract. The concluding faragraph of the seetion states: "Any employee who engages in a strike [in violation of this section] shall lose his status as an employee ... for the purposes of sections" S-10 of the NLRA. While it can be argucd that UE's walkout in Marathon does not fall within the contemplation of this scetion breause it concerned interpretation of the contract rather than its modification, other cases have considered interpretation strikes within the purview of $\$ \mathbb{8}(\mathrm{d})$. Sce Wagner Iron Worls, 104 N.I.R.B. No. 62, 32 LaB. Rer. Rer. Mans. 1104, 1108 (1953) ; Mastro Plastics Corr., 103 N.L.R.B. 511, 517 (1953) ; H.N. Thayer Co., 99 N.L.R.B. 1122, 1132 (1952). The Board in Marathon Electric Mff. Corp., 106 N.L.R.B. No. 199, 32 L.1B. Reb. Ref. Mas:. 1645 (1953), made passing mention of UE's non-compliance with $\$ \&(d)$. Id. at 3, 32 LAd. Rer. Rer. MaAT. at 1646 .

38. Although the Board invalidated the recognition granted by Maration to IBEW, sce note 33 stpra, IBEW was certified as bargaining agent for Marathon employees on February 2, 1954 after an election was held. Communication to the Yale Law Jouranal from Calvin O. Crocker, Labor Relations Director, Mfarathon Electric Affg. Corp., dated Iray 17, 1954, in Yale Law Library.

39. Marathon Electric Mfg. Corp., 106 N.L.R.B. No. 199, p. 4, 32 LaR. Rez. ReF. MI 1645,1647 (1953). While the offer to rehire was conditional upon a return as new employees, with loss of accrued benefits, the tone of the letter was apologetic: "You [the discharged employees] should know that, mafortunately, this union action forces us to consider everyone who is rehired as new employees." Ibid. (emphasis supplied). The workers who accepted Miarathon's offer were in fact restored to full seniority. Communication to the Yale Law Journal from Calvin O. Crocker, Labor Relations Director, Marathun Electric Mifg. Corp., dated May 17, 1954, in Yale Law Library.

40. These actions included the discriminatory discharge of six employees because of UE membership, see note 33 supra; the rescission of UE's contract, ste text at notes 46-56 infra; and active solicitation of a new union, see text at nutes 57-60 infro. 
An employer desiring to invoke sanctions against an unlawful union-sponsored walkout is not forced to discharge the strikers and rescind the contract: he has the option of continuing the contract and submitting his disciplinary measures to arbitration. ${ }^{41}$ Arbitrators, who must consider a continuing labormanagement relationship as well as responsibility for individual violations, usually allow discharge only of the leaders and instigators of an unlawful walkout. ${ }^{42}$ The Board itself has approved this type of employer sanction. ${ }^{43}$ The NLRB will not, howerer, invalidate employer disciplinary measures, regardless of harshness, unless they discriminate against workers because of union membership. ${ }^{44}$ And the Board is clearly under no obligation to apply arbitrators' standards as to the reasonableness of employer discipline. But when employer measures such as mass discharge go far beyond normal disciplinary requirements, the Board might well consider them as evidence of discrimination. ${ }^{45}$

41. About 89 percent of all collective bargaining agreements contain provisions calling for arbitration between the parties. BNA, Collective Barguning Necotintions AND Contracts $15: 130$ (1954). The procedure is initiated on an appcal by the union from the employer's determinations. Some contracts, however, allow no appeal, or an appcal only upon the issue of participation and not upon the penalty invoked. 1 ld at $15: 328-9$.

While, at common law, contracts to arbitrate cannot be specifically enforced, sce Sturges, Commercial Arbitrations and Awards, 45 (1930), several courts have construed Section 301 of the LRMA, 61 STAT. 156, 29 U.S.C. $\$ 185$ (Supp. 1952), as allowing a union to compel the employer to arbitrate an unauthorized walkout if there is a contract to arbitrate. Textile Workers Union of America v. American Thread Co., 113 F. Supp. 137 (D. Mass. 1953) ; Textile Workers Union of America v. Alco Mfg. Co., 94 F. Supp. 626 (M.D.N.C. 1950). See discussion in ABA Report, 21 Geo. WASH. L. REv. 127, 134-43 (1952).

42. See, e.g., Swift \& Co., 12 LAB. Arb. Rep. 108 (1948); Gloucester Fisheries, 5 LAn. ARB. Rep. 466 (1946); Bethlehem Steel Co., 2 Lab. ARB. REp. 194 (1945).

See, generally, ABA Report, 21 Geo. WAsh. L. Rev. 127, 157-70 (1952); Daylin, The No-Strike Clause, 11 U. of Pitr. L. Rev. 13, 18-34 (1949) ; P-H Union Cont. Serw. If 53,402 for discussion of arbitrators' handling of problems relevant to no-strike violations. See also cases cited in P-H Lab. ARb. Serv. IT 65,351-71.4 (1954).

43. See Fafnir Bearing Co., 73 N.L.R.B. 1008 (1947). There the employer unconditionally offered to reinstate all workers who struck in violation of contract and thereby was held to have waived his rights under the no-strike clause. See note 8 supro. Whan the workers returned, the employer refused to reinstate the union leaders and several other workers. The court held that the union leaders could be validly discharged but all other workers were covered by the waiver. Cf. NLRB v. E.A. Laboratories, Inc., 188 F.2d 885 (2d Cir. 1951) ; NLRB v. Dorsey Trailers, Inc., 179 F.2d 589 (5th Cir. 1950) (employer justified in discharging only union leaders).

44. "An employer may discharge an employee for a good reason, a poor reason or no reason at all so long as the provisions of the National Labor Relations Act are not violated." Edw. G. Budd Mfg. Co. v. NLRB, 138 F.2d 86, 90 (3d Cir. 1943). Accord: Wyman-Gordon Co., v. NLRB, 153 F.2d 480 (7th Cir. 1946); American Smelting and Refining Co. v. NLRB, 126 F.2d 680 (8th Cir. 1942). See cases cited in P-H LAw. RuL. SERV. II $21,201 \multimap 81$ (1954).

45. The Board has considered excessive severity as evidence of discrimination agatinst individuals. See, e.g., McCann Steel Co., 106 N.L.R.B. No. 6, 32 LAB. Rel. ReF. MAN. 1398 (1953) ; Precast Slab \& Tile Co., 88 N.L.R.B. 1237 (1950); but cf. Wyman-Gordon Co., 
The Board's validation of Marathon's contract rescission also appears unsound. In collective bargaining contracts, where a large number of minor violations are within the expectation of both parties, ${ }^{40}$ rescission is not justified by every breach of contract. ${ }^{47}$ However, there is precedent stating that a "material breach" by one party to a collective bargaining agreement enables the other party to rescind the contract. 4 Material breach by the union would probably be effected by a strike of substantial size and duration, ${ }^{49}$ and might be effected by a concerted slowdown. ${ }^{50}$ In Marathon, UE had been bargaining agent since 1937, and the violation occurred after seven months of a one-year contract.51 The UE members walked out to attend a union meeting, not to strike $;^{52}$ and even though Marathon might not have been expressly informed

153 F.2d 480 (7th Cir. 1946) (court felt employee's conduct justified severe nenalty). See also cases cited P-H LAB. REL. SERV. T 21,361 (1954).

46. The presence of grievance procedures in almost all contracts, see note 1 sifira, is an acknowledgement of the fact that contract violations are expected. See ALA Report, 21 Geo. W.ASH. L. REv. 127, 159 (1952).

47. See Boeing Airplane Co. v. International Association of Xachinists, $91 \mathrm{~F}$. Supp. 506, 608-9 (W.D. Wash. 1950) ; Kennedy v. Westinghouse Electric Corp., 25 N.J. Suger 601, 607, 96 A.2d 720, 723 (1953). Cf. Textile Workers Union of America v. Alco MIfg. Co., 94 F. Supp. 626 (MI.D.N.C. 1950) (unauthorized strike did not relieve employer of ubligation to arbitrate).

48. The history of unilateral rescission in labor relations situations is surprisingly limited. Marathon represents only the third case in which the problem has apgeared before the Board. In Boeing Airplane Co., 50 N.L.R.B. 447 (1948), the Board avoided the rescission problem by finding that the contract had expired prior to the strile. However, the Court of Appeals found the contract still in effect, and upheld the employer's rescission. NLRB v. Boeing Airplane Co., 174 F.2d 988 (D.C. Cir. 1949). In United Elastic Corp., S4 N.L.R.B. 768 (1949), the Board, in allowing a mass discharge, expressly refused to rule on the validity of the employer's rescission. Id. at 774 n.13. In a suit under Section 301 of the LRMIA growing out of the no-strike violation in NLRB v. Bosing Airplane Co., supra, the court without discussion found a material breach by the union. Therefore it held the employer's rescission was valid and a bar to his recovery in damages. Boeing Airplane Co. v. International Association of Machinists, 91 F. Supp. 596 (W.D. Wash. 1950), aff'd, 188 F.2d 356 (9th Cir.), cert. dcricd, 342 U.S. \&21 (1951).

Three state courts have recognized the right of an employer unilaterally to rescind a collective bargaining agreement. See Crandsll v. Thrifty Drug Stores Co, $5 \mathbf{~ C C H}$ Lab. Cas. If 60,846 (Calif. Sup. Ct. 1941) ; Zaritshy v. Lish, 95 N.Y.L.J. 346 (Sup. Ct. Jan. 20, 1936); see Kennedy v. Westinghouse Electric Corp. 25 N.J. Sup 4 r. 601, 607, 90 A.2d 720, 723, rev'd on other grounds, 29 N.J. Super. 6S, 101 A.2d 592 (1953).

49. See Crandell v. Thrifty Drug Stores Co., 5 CCH L.a. Cas. T 60,845 (Calif. Sup. Ct. 1941) ; Zaritsky v. Lish, N.Y.L.J. 346 (Sup. Ct. Jan. 20, 1936). Some contracts spacify a strike of substantial duration before rescision becomes available as a remsdy to the employer. See, e.g., Agreement between Bendix Aviation Corp. and UAW-CIO (1950) (strike must last 10 days); Agreement between General Mfotors Corp. and UAW-CIO (1948) (same).

50. See Kennedy v. Westinghouse Electric Corp., 25 N.J. Super. 601, 005,96 A.2d 720, 723, rev'd on other grounds, 29 N.J. Surer. 6\$, 101 A.2d 502 (App. Div. 1953).

51. Communication to the Yale Law Joctanal from Calvin O. Crocker, Labor Relations Director, Marathon Electric Mifg. Corp., dated May 17, 1954, in Yale Law Library.

52. Marathen Electric Mfg. Corp., 106 N.L.R.E. No. 199, p. 7, 32 L.10. RrL. Rer. MAar. 1645,1647 (1953). This work stoppage violated UE's no-strilie clause as much as a formal 
that the walkout was over, a majority of union workers appeared at the plant gates the next day, five days before Marathon's rescission. ${ }^{63}$ Granting that the walkout constituted a breach of contract subjecting the union members to discipline, ${ }^{54}$ it is at least questionable whether the breach was sufficiently material to justify rescission..$^{55}$ Yet the board did not discuss this issute. ${ }^{.0}$

Moreover, the Board should have considered Marathon's contract rescission not as an independent act but as one step in a co-ordinated plan to oust UE as bargaining agent. The rescission, following the mass discharge, enabled Marathon to hire a substantially new working force, without having to rehire a nucleus of laid-off UE workers under the contract. ${ }^{57}$ By virtue of the rescission, the newly hired workers were not bound to UE under the old contract. ${ }^{58}$ And Marathon's refusal to bargain with UE after the rescission was

strike would have. Ibid. However, the reasons why the workers left the plant bear upon the materiality of the union's breach.

53. Ibid.

54. See note 52 supra.

55. There has been no discussion of what factors constitute a material breach of a collective bargaining agreement. See note 48 supra. Moreover, in the analogous field of continuing performance contracts, there is no clear delineation of material breach. Commentators have concluded merely that a material breach is one that goes to the heart of a contract and enables the other party to rescind, while an immaterial breach is an insubstantial or technical one which may be adequately compensated for by damages. Sec Simpson, Contracts § 154 (1954); Williston; Contracts $\$ 841$ (Rev'd Ed. 1936).

However, there is support for holding that UE's brcach in Marathon was not sufficiently material to justify rescission. The appearance of the workers at the plant gate and the union's desire to negotiate concerning the end of the walkout might be construed as evincing a desire to be bound by the contract after a walkout of only a single day. Scc, e.g., Pasquel v. Owen, 186 F.2d 263 (8th Cir. 1950) (in baseball player-manager's fivc-ycar contract, termination of his managership duties by employer did not justify rescission by player when employer had not refused to be bound by the contract in the future); Parnmount Pictures, Inc. v. Maxon, 226 Iowa 308, 284 N.W. 119 (1939) (in one-year movic supply contract, failure of supplier to furnish one movie of two days' run did not justify rescission by exhibitor). But cf. Nickel v. Pollia, 179 F.2d 160 (10th Cir. 1950) (conltractor's rescission justified when subcontractor stopped work pending settlement of disputes between the parties). The Board also neglected to consider whether the cmployer's mass discharge under the penalty provisions of the contract, see text at note 16 supra, was an affirmance of the contract subsequent to the breach. Affirmance generally will bar rescission. See Black, Rescission and Cancellation $\$ \$ 594-5$ (2d Ed. 1929). but c/. Boeing Airplane Co. v. NLRB, 174 F.2d 988 (D.C. Cir. 1949) (simultaneous discharges and rescission upheld); United Elastic Corp., 84 N.L.R.B. 768 (1949) (discharges upheld after rescission).

56. It may be argued that the undiluted principles of contract law should not apply to a collective bargaining agreement, which presupposes a continuing relationship between employer and union and an absence of real economic alternatives for cither party. Sec Chamberlain, Collective Bargaining and the Concept of Contract, 48 CoL. L. Rev. 829 (1948); Witmer, Collective Labor Agreements in the Courts 48 YALE L.J. 194, 209-10 (1938).

57. See text at note 33 supra.

58. If the old contract remained in effect, its union shop provisions, sce note 30 supra, required newly hired employees to join UE. See P-H Unron ConT. Swev. IfI 53,137 (1954). 
followed by its active solicitation of another union during the rehiring period.98 For a material violation of its contract, a union should perhaps be clastised by recission, which may allow an employer to renegotiate the escential terms of the contract to his advantage. But if, as in Marathon, rescission is designed not to discipline the union but to enable the employer illegally to assist in the development of a new union, ${ }^{60}$ it should be disallowed.

The tactic of mass discharge and contract rescission condoned by the Board in Marathon works severe hardship upon individual union members. It places all union members, regardless of participation or leadership in the strilie, at the mercy of the employer as to the terms of re-employment: he may refuse to rehire any members of the striling union ${ }^{61}$ or he may rehire them only with loss of seniority rights and accrued benefits. ${ }^{62}$ MIoreover, the rescission prevents the employees from testing the materiality of their union's breach and the validity of their own discharges through the grievance procedures.

The only way, apparently, for the individual to escape penalties is by disassociation from the union's illegal acts. ${ }^{04}$ But it is unrealistic to expect this action

59. See text at note 20 suigra.

60. The support and solicitation of IEEW by Marathon was rightly considercd a violation of Section S(a) (2) of the NLRA which prohibits an employer from duminating or interfering with the formation of a labor union. 49 Sr.st. 452 (1935), os anterddd, 61 Stat. 140 (1947), 29 U.S.C. $\$ 158$ (Supp. 1952). See casts cited in P-H Lab. Rer. Scrw. IfT 20,911-21,011 (1954). Despite the Board's invalidation of IBEW"s recognition, that union was soon validly certified as bargaining agent for Marathon emyloyces. Sce nute 38 supra.

61. In Marathon, the company rehircd only 49 out of 550 discharged UE membars. Communication to the Yale Law Jouniar from Calvin O. Crueler, Lab ar Ruiatiens Director, Marathon Electric Mifg. Corp., dated May 17, 1954, in Yale Law: Lilhrars. Its alility to hire a substantially new working force probably resulted from the small sizs of its plant and a depressed employment market. In the normal case, the employcr must rehire most of the strikers in order to reopen. See United Elastic Curp., \&4 N.L.R.E. 76S (1949) (employer made two unsuccessful offers of ruinstatement before discharging striling workers); Fafnir Bearing Co., 73 N.L.R.B. 1003 (1947) (employer reinstatud cntire worl: force two months after commencement of illegal strike).

62. NLRB v. Sands MIfg. Co., 306 U.S. 332, 345 (1939) (cmpluyer e vid offer reemployment at different terms to validly discharged employees); United Elastic Corp., \&4 N.L.R.B. 768, 777 (1949) (employer justified in rehiring sume dischargud workers and refusing to rehire others); Scullin Steel Co., 65 N.L.K.L. 1394, 1318 (1946) (employer justified in refusing reinstatement to all discharged strikers). 22 GEo. WASr. L. Rar. 243 (1953) suggests that Marathon may allow the employcr to place what in other circumstances would be illegal conditions upon the rehiring of discharged workers: loss of seniority and abandonment of UE. $S e$ Wilion \& Co. v. NLRB, 120 F.2d 913, 924 (7th Cir. 1941).

63. If the contract had remained effective, Marathon's pcnalties would have bsen revieved by an arbitrator. See Brief for General Counsel, p. 19, Marathon Elcetric Mffg. Corp., 106 N.L.R.B. No. 199, 32 LaB. ReL. Ref. MAst. 1645 (1553). While the NLRB did review the penalties, an arbitrator would probably have disallowad the mass discharge. See text at note 42 supra.

64. Marathon Electric Mfg. Corp., 106 N.L.R.B. No. 199, 32 L.1B. Ren. Rer. MIa: 1645 (1953). See note 30 stfra. Cf. Polish National Alliance v. NLRB, 136 F.21 175, 181 (7th Cir. 1943) (worker who disassuciatud himself from the rest of unfair latur 
in a union with any internal solidarity. ${ }^{65}$ And the requirement of disassociation runs counter to federal labor legislation, which encourages collective activity through unions. ${ }^{68}$ It is particularly unreasonable to expect an individual member to disassociate himself from his union when there is a chance that the union may be justified in its actions. ${ }^{.7}$ The issues surrounding the legality of a strike are usually clouded at the time of the strike, and participation by union members is usually based upon information given by the union leadership and acquiescence in leadership maneuvers. ${ }^{68}$

Invalidation of mass discharge and rescission in a situation such as Marathon does not unduly limit the employer. He may refuse to bargain with the union until the strike is terminated. ${ }^{90}$ He may hire new workers during the strike and need not reinstate workers whose jobs have been filled. ${ }^{70} \mathrm{He}$ may discipline strike leaders by discharge ${ }^{71}$ and strike participants by reasonable lesser-than-discharge penalties. ${ }^{72}$ And he has the opportunity of calling for a new representation election if he believes that the striking union has lost

practice strikers given back pay from day of disassociation and application for reinstatement) ; Pacific Tel. \& Tel. Co., 107 N.L.R.B. No. 301, 33 Lan. Ret. Rer. Man. 1433, 1436 (1954) (employer did not lock out non-striking employees who had not disassociated themselves from union's strike).

65. In Marathon, none of the 62 absentees took any steps to disassociate himself from the union, and 9 out of 11 polled UE workers stated they would not have accepted any offer of reinstatement which did not include all other members of the local. Marathon Electric Mfg. Corp., 106 N.L.R.B. No. 199, p. 10, 32 LAB. ReF. MaN. 1645, 1647-8 (1953).

66. Section 1, NLRA, 49 STAT. 449 (1935), 29 U.S.C. \& 151 (1946); see statement of Senator Taft in Hartlex, OUR New National Labor Policy, p. xiv (1948).

67. If a no-strike violation has been precipitated by the employer's unfair labor practice, it is the Board's rule to condone the violation and order reinstatement of all discharged workers. Mastro Plastic Co., 103 N.L.R.B. 511 (1953). Sec Joseph Dyson \& Sons, Inc., 72 N.L.R.B. 445, 447 (1947); Scullin Stcel Co., 65 N.L.R.B. 1294, 1318 (1946). But cf. National Electric Products Corp., 80 N.L.R.B. 995 (1948) (unfair labor practice does not justify no-strike breach).

68. See Daykin, The No-Strike Clause, 11 U. PITr. L. Rev. 13, 30-1 (1949). During World War II, the War Labor Disputes Act, 57 Stat. 163 (19+3), 50 U.S.C. App. $\$ 1501$. 15 (1946), provided for thirty days notice of strikes at war plants and for a secret ballot the thirtieth day. In an overwhelming number of cases, the employees votcd with the union leadership. N.Y. Times, January 12, 1954, p. 9, col. 3 .

69. See note 27 supra.

70. During the course of an economic strike, the employer is free to hire as many new employees as he wishes. NLRB v. Mackay Radio \& Telegraph Co., 304 U.S. 333 (1938). See cases cited in P-H LAB. REI. SERv. $\llbracket 21,136$ (1954). A fortiori, he should be free to hire new employees during the course of a contract-violating strike, as in Marathon. See Fafnir Bearing Co., 73 N.L.R.B. 1008, 1014-16 (1947). However, if the strike was precipitated by the employer's unfair labor practice, all strikers are entitled to reinstatcment. See note 67 supra.

71. See note 43 supra.

72. Several types of lesser-than-discharge penalties have been upheld. Sce, c.g., NLRB v. Dorsey Trailers, Inc., 179 F.2d 589 (5th Cir. 1950) (two weck lay-off); Pacific Tel \& Tel. Co., 107 N.L.R.B. No. 301,33 LAB. Ret. Ref. MAN. 1433 (1954) (loss of wages); National Electric Products Corp., 80 N.L.R.B. 995 (1948) (suspension for several days). However, one state court has held that the employer could not invole 
its majority. ${ }^{73}$ Furthermore, the employer may recover the losses incurred because of the strike by suing the union under Section 301 of the Labor Management Relations Act. ${ }^{74}$ While employers should not be handicapped in their use of reasonable strike sanctions, they should not be allowed under the guise of such sanctions to change their employees' union.

penalties not specified by the contract. See Kennedy v. Westinghause Elestric Corp., 25 N.J. Super. 601, 96 A.2d 720, reid on other grounds, 29 N.J. Suner. C\$, 101 A.2d 592 (1953). Accord: Sylvania Electric Products Co, 14 LAB. Arn. Res. 16 (19:0) (employer could discharge illegal strikers under terms of contract, but it could not cuspand them for two weeks).

Prentice-Hall advises its employer-subscribers to secure specific lesser-than-dicclarge penalties in contracts. See P-H Unron CoNT. SERv. REP. T S2 (Oct. 19, 1933). Aming its recommended penalties are loss of bonuses, loss of seniority, and loss of accrud vacation time.

73. In order to hold a representation election, the employer must be confronted by claims of recognition from one or more labor organizations; and no election can ha demanded in the 12-month period subsequent to an election. $\$ \$ 9$ (c) (1)(b), $9(\mathrm{c})(3), 61$ STAT. 144 (1947), 29 U.S.C. \$ 159 (Supp. 1952).

If, after the strike, the employer has a rcasonable doubt as to the evistence of a majority in the existing union, he may refuse to bargain until an election has been held. See caces cited in P-H Lab. Ket. Serv. If 21,942-3 (1954). See also NLRB v. Dorsey Trailers, Inc., 179 F.2d 589 (5th Cir. 1950) (employer may refuse to bargain with union uron termination of illegal strike until NLRB proves union still represents a majority of workers).

Recognition of a new union without an election will probably be disallowed. Marathon Electric Mfg. Corp., 106 N.L.R.B. No. 199, p. 17, 32 L.AB. Rez. Rer. Mar. 1645, 1650 (1953).

74. Section 301, 61 Stat. 156 (1947), 29 U.S.C. \$ 185 (Supp. 1952). For an analysis of Section 301 cases through 1952, see ABA Report, 21 GEo. WAsr. L. Rev. 127, 123-44 (1952).

Rescission of contracts has been held a bar to Section 301 relief on an election of remedy theory. See Boeing Airplane Co. v. International Associatiun of Machinists, 91 F. Supp. 596 (W.D. Wash. 1950), aff'd, 18S F.2d 356 (9th Cir.), cert. dericd, 342 U.S. $\$ 21$ (1951). 